УДК: 374.7 .013

DOI: https://doi.org/10.35387/od.2(20).2021.89-101

Коваленко Лариса Василівна кандидат педагогічних наук, завідувач відділу української мови та літератури, мов національних меншин $i$ зарубіжної літератури комунального закладу вищої освіти «Вінницька академія безперервної освіти»
Kovalenko Larysa - Candidate of Pedagogical Sciences, Head of the Department of Ukrainian Language and Literature, the Minority Languages and World Literature of the Public Higher Education Establishment «Vinnytsia Academy of Continuing Education»

ORCID iD: https://orcid.org/0000-0002-3076-1279

E-mail: larisacowalenko21@gmail.com

Шевченко Ілона Андріївна кандидат педагогічних наук, доцент кафредри екології, природничих та математичних наук комунального закладу вищої освіти "Вінницька академія безперервної освіти"
Shevchenko llona - PhD in Pedagogics, Assistant Professor of the Department of Ecology, Natural and Mathematical Sciences of the Public Higher Education Establishment "Vinnytsia Academy of Continuing Education»

ORCID iD: https://orcid.org/0000-0001-5585-8547

E-mail: dilon2808@gmail.com

\title{
СУЧАСНА БЕЗПЕРЕРВНА ПЕДАГОГІЧНА ОСВІТА ЯК СОЦІОКУЛЬТУРНИЙ ФЕНОМЕН
}

Анотація. В оглядовій статті розглянуто специфріку сучасної безперервної педагогічної освіти як об'єкта наукового дослідження з позиції ії соціальної природи, як складової освітньої практики та соціальнокультурного середовища, спрямованого на удосконалення професійної діяльності педагогічних працівників.

Здійснено соціально-культурологічний підхід до вивчення особливостей організації та сфрер діяльності системи безперервної педагогічної освіти у системі післядипломної педагогічної освіти у зв'язку з потребою практичної реалізації завдань реформування сучасної освіти.

Схарактеризовано основні особливості загальнодержавної системи освіти, освітніх цілей, змісту, моделей, видів та форм отримання освіти на різних рівнях та визначено умови ефективності післядипломної освіти як системи передачі знань, умінь, технік, методик, технологій, вироблених стандартів: безперервний розвиток, оновлення та орієнтація на майбутнє; відповідність часу і грунтування на стратегії розвитку суспільства і людини в ньому. 
Представлено такі моделі професійного розвитку педагогів у системі безперервної педагогічної освіти, як компетентнісну, пролонговану, диференційовану, диверсифріковану, особистісно орієнтовану, у співвідношенні з основними моделями сучасної освіти - традиційною моделлю (Ж. Мажо, Л. Кро, Ж. Капель, Д. Равич, Ч. Фінн та ін.), раціоналістичною моделлю (П. Блум, Р. Ганьє, Б. Скіннер та ін.), моделлю розвивальної освіти (В. Давидов, В. Рубцов та ін.), феноменологічною (А. Маслоу, А. Комбс, К. Роджерс та ін.), неінституціональною моделлю освіти (П. Гудман, І. Ілліч, Ж. Гудлед, Ф. Клейн, Дж. Холт, Л. Бернар і ін.).

Визначено концептуальні аспекти соціокультурного підходу до формування змісту безперервної педагогічної освіти: світогляднофрілософфський; соціальний; методологічний; психологічний; дидактичний; методичний.

Ключові слова: безперервна педагогічна освіта; компетентність вчителя; соціальний підхід; культурний підхід.

\section{Kovalenko Larysa, Shevchenko llona}

\section{MODERN CONTINUOUS PEDAGOGICAL EDUCATION AS A SOCIO-CULTURAL PHENOMENON}

Abstract. The review article deals with the specific of modern continuing pedagogical education as an object of scientific research from position of its social nature, as a component of educational practice and socio-cultural environment which are directed to the improvement of professional activity of pedagogical workers. The social-culturological approach to the study of organizational features and spheres of activity of the system of continuing pedagogical education in the system of retraining pedagogical education in connection with the necessity of practical realization of tasks of reformation of modern education has done. Also it is determined the efficiency of teacher's retraining education as a system of transmission of knowledge, abilities, technics methodologies, technologies, standards: a continuous development, updating and orientation on the future; corresponding the time and bases on the strategy of the development of society and a man. Such models of professional development of teachers are presented in the system of continuous pedagogical education, as prolonged, differentiated, diversified, personality oriented one, in correlation with the basic models of modern education - traditional model (Zh. Mazho, L. Kro, Zh. Drops, D. Ravich, Ch. Finn etc.), model of rationalism (P. Blum, B. Skiner and others ), model of developing education (V. Davydov, V. Rubtsov and others), phenomenological (A. Maslow, A. Kombs, K. Rojers and others), uninstitutional model of education (P. Gudman, I. Illya, Zh. Gudlet, F. Klein, D. Holt, L. Bernar and others ). It is determined the conceptual aspects of the social-culturological approach of forming content of continuous pedagogical education: philosophical; social; methodological; psychological; didactical; methodical. The authors described the basic features of the national system of education, educational aims, maintenance, models, kinds and forms of acquisition of education on different levels. The models of professional development of teachers are presented in the system of continuous pedagogical education in correlation with the basic models of modern education. 
Key words: continuous pedagogical education; teacher's competence; social approach; cultural approach.

Постановка проблеми, їі актуальність. На початку третього тисячоліття світ вкотре переконався, що розвиток будь-якого суспільства, запобігання екологічним, економічним, політичним кризам і національним конфрліктам - усе це тісно пов'язано з рівнем освіченості та культури людей. В умовах наростання великої кількості різноманітної інформації й бурхливих змін у соціально-економічній сфері потрібне істотне коригування пріоритетів і акцентів у системі знань сучасної людини. Поряд 3 традиційними проблемами навчання і виховання перед сучасною освітою стоїть проблема розвитку планетарного мислення особистості, яка діє в дусі загальнолюдських цінностей і готова цивілізовано вирішувати глобальні національні, екологічні, економічні та інші завдання. Як основа соціального, політичного, економічного, духовного та культурного розвитку суспільства, освіта проголошена державним пріоритетом країни. Для системи освіти надважливо шляхом глобального аналізу сучасних знань людства з'ясувати, чого саме і як результативно навчати наступне покоління громадян. Як зберегти фізичне та психічне здоров'я людини, запобігти зайвим перевантаженням, інформаційним неврозам? Як допомогти реалізуватися творчій особистості? Очевидно, що сучасна освіта має бути тією галуззю соціокультурної життєдіяльності, де відбувається становлення духовно зрілої, свідомої, вільної і творчої особистості, спроможної берегти загальнолюдські цінності, творити цілісний гуманний світ.

Практична реалізація завдань, зумовлених реформуванням освіти, залежить насамперед від педагогів, здатних вільно й творчо орієнтуватися в соціальних і природних явищах, феноменах культури, процесах інтеграції, що відбуваються в науці та практиці. Сучасна безперервна педагогічна освіта у системі післядипломної педагогічної освіти за умов освітніх реформ в Україні вирішує важливі завдання, пов'язані 3 професійним розвитком педагогічних працівників. 3 цих позицій метою безперервної педагогічної освіти $€$ забезпечення розвитку компетенцій сучасних педагогічних працівників відповідно до викликів часу, запитів освітньої практики та суспільства.

Сучасна профеесійна діяльність педагога ґрунтується на безперервній освіті та самоосвіті, у процесі яких мають розвиватися всі компоненти педагогічного досвіду та особистісні якості - культурні, комунікативні, пізнавальні, естетичні, фрізичні; компоненти предметної діяльності (знання та вміння); творчі здібності. Особливості професійної діяльності детермінують розвиток загальнокультурної, фахової та функціональної складових сукупної культури педагога в їхній єдності та визначають наскрізні складові післядипломної педагогічної освіти: фраховокваліфікаційну, функціональну та загальнокультурну, що традиційно $€$ напрямами підвищення кваліфікації педагогічних працівників.

Аналіз актуальних досліджень і публікацій. Тенденції 
становлення особистісно-гуманної освіти 3 її культуротворчою та гуманітарною функціями детермінують зміни в методології післядипломної педагогічної освіти у напрямі розвитку особистості педагога як суб'єкта культури. У цьому контексті актуалізується питання законодавчого й нормативно-правового забезпечення безперервної педагогічної освіти. О. Баніт проаналізувала концептуальні положення неперервного професійного розвитку у міжнародних документах (Баніт, 2016), Л. Лук'янова й О. Аніщенко звертають увагу на нові можливості для розвитку педагогічної освіти і практики (Лук'янова, Аніщенко, 2017).

В. Олійник розглядає підвищення педагогічної кваліфікації в системі безперервної освіти як процес і результат навчання педагогічних працівників, головною метою якого $€$ забезпечення потреб суспільства в кваліфікованих кадрах з високим рівнем професіоналізму та культури, спроможних компетентно, творчо й відповідально виконувати завдання (Олійник, 2001, с. 94).

Проблеми освіти як соціокультурного феномена розглядалися Ю. Азаровим, Л. Даниленко, І. Зязюном, В. Каплінським В. Кременем, В. Ортинським та іншими науковцями. Аналіз наукових досліджень дав можливість визначити соціокультурний аспект освіти взагалі та безперервної освіти зокрема як процес формування та вдосконалення світогляду суб'єкта і як рівень знань, умінь, навичок, заснованих на певних здібностях, цінностях, потребах. Відтак освіта постає як соціальна цінність, і саме цінності виступають у якості мотиваторів досягнення поставленої мети.

Мета статті - визначення місця, та ролі безперервної педагогічної освіти в сучасних освітніх процесах у контексті світового культурного розвитку та історичних закономірностей; пошук шляхів поєднання фундаментальних теоретичних знань з практикою підвищення кваліфікації педагогічних працівників у системі безперервної педагогічної освіти, опанування сучасним інструментарієм освітньої діяльності для повнішої реалізації гуманітарної та культуротворчої функцій, забезпечення гармонізації науково-предметних, світоглядно-методологічних, дидактичних, психологічних знань та соціокультурних, морально-етичних цінностей вчителя.

Виклад основного матеріалу дослідження. Функціонування будь-якої освітньої системи підпорядковане певній меті та освітнім цілям. Одна з наймасовіших радикальних освітніх реформ в Україні, що відображена в Концепції «Нова українська школа» (Про схвалення Концепції реалізації державної політики у сфері реформування загальної середньої освіти «Нова українська школа», 2017), спрямована на модернізацію системи вітчизняної освіти, зумовлену інтеграцією в глобальний світовий, зокрема європейський освітній простір, адаптацією до нових соціально-економічних відносин, необхідністю забезпечення конкурентоспроможності освіти в інформаційному суспільстві, переорієнтацією освітнього процесу на розвиток особистості.

Упровадження освітніх реформ, їх ефективність значною мірою залежить від науково-теоретичного обґрунтування змін і розробки 
механізмів їхньої реалізації. Національна доктрина розвитку освіти одним із пріоритетних напрямів державної політики щодо розвитку освіти визначає розвиток системи безперервної освіти та «навчання протягом життя».

У Законі України «Про освіту» визначення поняття «освіта» подається як «цілеспрямований процес навчання і виховання в інтересах особистості, суспільства, держави, що супроводжується констатацією досягнень людьми, які навчаються, певних державних освітніх рівнів цензів». Зокрема у статті 6 Закону «Про освіту» зазначено, що «засадами державної політики у сфері освіти та принципами освітньої діяльності $є$ нерозривний зв'язок зі світовою та національною історією, культурою, національними традиціями, вихованням патріотизму та поваги до культурних цінностей українського народу, його історико-культурного надбань і традицій, формуванням громадянської культури» (Закон України «Про освіту», 2021).

Відповідно до Закону України «Про вищу освіту» «вища освіта $€$ сукупністю систематизованих знань, умінь і практичних навичок, способів мислення, професійних, світоглядних і громадянських якостей, моральноетичних цінностей, інших компетентностей, здобутих у закладі вищої освіти (науковій установі) у відповідній галузі знань за певною кваліфікацією на рівнях вищої освіти, що за складністю $є$ вищими, ніж рівень повної загальної середньої освіти» (Закон України «Про вищу освіту», 2012).

Останнім часом у всьому світі активізувалися дослідження, пов'язані з теорією і практикою конструювання навчальних предметів, курсів, побудовою освітніх планів і програм. Ця тенденція світової педагогіки є природною, оскільки викликана науково-технічним прогресом i потребами в постійному удосконаленні освіти. Сучасна освіта і безперервна педагогічна освіта зокрема, яка постає як соціальна цінність $\mathrm{i}$ мотиватор досягнення поставленої мети, має бути різноваріантною. Повноцінний інтелектуальний, соціальний і моральний розвиток людини це результат реалізації всіх фрункції освітнього процесу в їх єдності. Поряд 3 цілеспрямованим і спеціально організованим процесом навчання i виховання в умовах конкретної освітньої системи людина протягом всього життя включена в процес самоосвіти. Свого часу Д.І. Писарєв слушно зауважив: «Хто цінує іншу думку, той дуже добре знає, що справжня освіта $\epsilon$ тільки самоосвіта і що вона починається з тієї хвилини, коли людина, розпрощавшись назавжди зі всіма школами, робиться повним господарем свого часу і своїх занять» (Писарев, 1956, с. 127).

Із забезпеченням розвитку всіх складників сукупної культури педагога безперервна освіта постає як спосіб розширення потенційних можливостей його професійного розвитку. Таким чином, актуальною $\epsilon$ необхідність здійснення культурно-освітнього підходу щодо змісту післядипломної педагогічної освіти, який визначений:

- спрямуванням нової освітньої парадигми на перенесення акцентів у навчанні на розвиток культури мислення, почуттів, поведінки особистості, реалізацію гуманітарної та культурологічної функцій освіти;

- значущістю національних культурних традицій, їх високим 
виховним потенціалом, підвищенням ролі народної педагогіки і культури у вихованні та соціалізації особистості.

Оскільки основним змістом поняття «підвищення кваліфікації» $€$ цільова складова, закономірності, принципи, форми, методи, технології, функції процесу та його змістові аспекти (Олійник, 2001), підвищення кваліфікації здійснює такі функції: програмно-цільові, процесуальнотехнологічні, соціально-психологічні. 3 позиції практики безперервної педагогічної освіти важливо знати специфіку всієї системи освіти на рівні країни, конкретного регіону та окремого освітнього закладу. Ця специфіка проявляється в моделях освіти, в освітніх цілях, змісті, формах, видах отримання освіти. Цілі і зміст як системоутворюючі будь-якого виду та рівня освіти визначаються державною політикою, розкриваються в освітньому стандарті і конкретизуються в реальному освітньому процесі на рівні кожної освітньої системи і кожної навчальної дисципліни.

Освітня макросистема, основними елементами якої є система шкіл - дошкільної, шкільної, середньої спеціальної, вищої, післядипломної освіти - передбачає пояснення поняття «школа» як тип освітньої системи або будівлю, в якій розміщується навчальний заклад. Однак поняття «школа» передбачає й загальнокультурний зміст. Латинською мовою «школа» (schol) означає сходи, які ведуть вгору. У перекладі з грецької мови «школа» (schole) - це будинок радості в процесі пізнання світу. Маючи релігійно-духовне походження, це поняття спочатку відображало об'єднання людей (вчителів і учнів), включених у процес сходження душі людини. У зв'язку з цим про школу говорили більше як про напрям або течію в науці, мистецтві, літературі, що має характерні властивості, методи, прийоми. Терміном «школа» характеризують також живопис, скульптуру міста або цілої країни у випадку, якщо їх своєрідність виражено в певних стилістичних і хронологічних межах - «болонська школа» або «фламандське мистецтво». Протягом століть складалися і продовжують з'являтися школи, які у педагогічному світі відомі як «Школа радості», «Вальдорфська школа», «Школа Френе», «Гуманітарна школа», «Музична школа», «Художня школа», «Економічна школа», «Школа життя» тощо.

Освітніми цілями $є$ чітко визначені очікувані результати, яких прагне досягти суспільство, країна, держава за допомогою сформованої системи освіти в цілому, в даний час і в найближчому майбутньому. Цілі соціально залежні від різних умов: від характеру суспільства, від державної освітньої політики, від рівня розвитку культури і всієї системи освіти і виховання в країні, а також від системи головних цінностей. У сучасних умовах при доборі цілей зазвичай враховуються як соціальний запит держави і суспільства, так і цілі, інтереси та схильності окремої людини.

Сучасна освіта взагалі й післядипломна освіта зокрема як системи передачі знань, умінь, технік, методик, технологій, вироблених стандартів дії і поведінки є ефективними, якщо: по-перше, безперервно розвиваються, оновлюються та орієнтовані на майбутнє, по-друге, відповідають часу і ґрунтується на стратегії розвитку суспільства і людини в ньому. Результативність освіти визначається ступенем реалізації цілей та 
освітнього стандарту, типом, якістю і рівнем освіти.

Європейський простір вищої освіти формується на засадах Болонського процесу, який передбачає структурне реформування національних систем вищої освіти країн Європи, зміну освітніх програм і проведення необхідних інституційних перетворень у вищих навчальних закладах Європи із збереженням національної палітри самобутності й надбань. Нам імпонують викладені у навчальному посібнику В. Ортинського теоретичний доробок педагогіки вищої школи попередніх поколінь, нові погляди і підходи до організації освітнього процесу у закладах вищої освіти в контексті Болонського процесу. Сучасна освіта розвивається в різних напрямах, їй притаманні гуманізація, гуманітаризація, диференціація, диверсифікація, стандартизація, багатоваріантність, багаторівневість, фундаменталізація, комп'ютеризація, інформатизація, індивідуалізація, безперервність (Ортинський, 2009, с. 73).

Вважаємо за доцільне зазначити, що в основу модернізованої системи безперервної освіти педагогічних працівників, як і керівних кадрів системи освіти, покладено принципи: демократизації (рівноправність, партнерство, вибір); гуманізації (взаємодопомога, взаєморозуміння, співпереживання); інтенсифікації (застосування сучасних комп'ютерних, телекомунікаційних, мультимедійних, дистанційних, ігрових, проєктних технологій); національної спрямованості (народні традиції); інтеграції (вивчення процесів і явищ через призму різних наукових теорій і течій); валеологізації (пріоритетність здорового способу життя); відкритості (прозорість прийнятих рішень); інноваційності (зміни, спрямовані на розвиток) (Даниленко, 2004).

Гуманітарний характер змісту безперервної педагогічної освіти закладений переважно в її загальнокультурній складовій, де визначено питання фрілософії, соціології, освіти, політології, культурології, економіки і права, однак потребує розширення тематика культурологічного циклу естетики, педагогічної етики, риторики тощо. Варті на увагу питання опанування знань сучасним педагогом з таких проблем, як: природа i культура; культура і творчість; національна культура та історія; світова та національна культура; педагогічна та методична культура тощо.

Модель освіти як державно-відомчої організації розглядається як самостійний напрям у низці інших галузей, у яких освітній процес відображає такі властивості: двобічність взаємодії надавачів та здобувачів освіти; спрямованість усього процесу на всебічний і гармонійний розвиток особистості; єдність змістової і процесуальної (технологічної) сторін; взаємозв'язок всіх структурних елементів: мети, змісту освіти і засобів досягнення освітніх завдань - результату освіти; реалізацію функцій розвитку, навчання та виховання.

Досвід запровадження моделей професійного розвитку вчителів в Україні активізувався із прийняттям Закону «Про освіту», в якому визначено нові підходи до безперервного професійного розвитку вчителя, зокрема відповідно до 59 статті зазначено, що «професійний розвиток педагогічних працівників передбачає постійну самоосвіту, участь у 
програмах підвищення кваліфікації та будь-які інші види і форми професійного зростання». Рефлексивна модель безперервної освіти педагогів може здійснюватися за різними видами (навчання за освітньою програмою, стажування, участь у сертифікаційних програмах, тренінгах, семінарах-практикумах, семінарах-нарадах, семінарах-тренінгах, вебінарах, майстер-класах тощо) та у різних формах (інституційна, дуальна, на робочому місці (на виробництві) тощо). Вид, форму та суб'єкта підвищення кваліфікації обирає вчитель.

У сучасному освітньому процесі професійного розвитку вчителів можна виокремити декілька моделей безперервної післядипломної педагогічної освіти - компетентнісну, пролонговану, диференційовану, диверсифіковану, особистісно орієнтовану та співвіднести їх з основними моделями сучасної освіти (табл. 1).

\section{Моделі професійного розвитку педагогів \\ у системі безперервної педагогічної освіти у співвідношенні до основних моделей сучасної освіти}

Таблиця 1

\begin{tabular}{|c|c|}
\hline Основні моделі сучасної о & $\begin{array}{c}\text { Модель професійного розвитку вчителя в } \\
\text { системі безперервної освіти }\end{array}$ \\
\hline $\begin{array}{l}\text { Традиційна модель освіти } \\
\text { Ж. Мажо, Л. Кро, Ж. Капель, } \\
\text { Д. Равич, Ч. Фінн та ін. }\end{array}$ & Компетентнісна модель \\
\hline 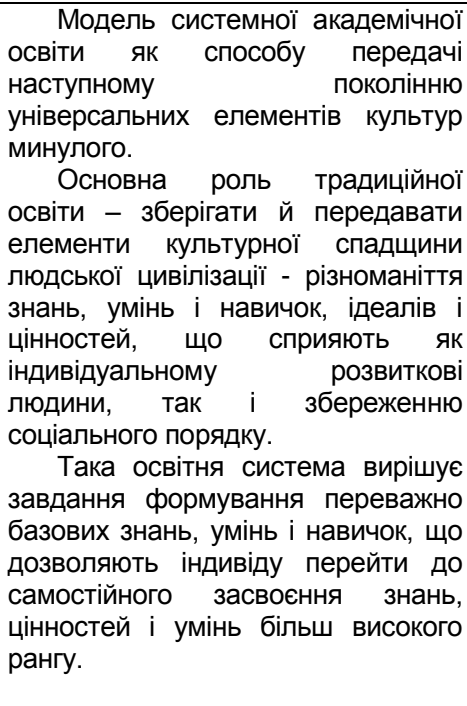 & $\begin{array}{l}\text { Передбачає єдність змісту курсів } \\
\text { підвищення кваліфікації, що проводиться на } \\
\text { базі інститутів післядипломної педагогічної } \\
\text { освіти, та міжкурсового періоду, спрямованих } \\
\text { на розвиток профресійних компетентностей за } \\
\text { уніффікованими освітніми програмами. } \\
\text { Більшість занять проходить за очною } \\
\text { формою навчання, також в закладах створено } \\
\text { сайти, блоги, які забезпечують використання } \\
\text { електронних освітніх ресурсів та надають } \\
\text { комп'ютерну підтримку слухачам у курсовий та } \\
\text { міжкурсовий періоди підвищення кваліфікації. } \\
\text { Соціально-культурний аспект підвищення } \\
\text { кваліфікації передбачає: підвищення рівня } \\
\text { освіченості та розвиток особистості; соціальне } \\
\text { успадкування і трансляцію культури; } \\
\text { урахування інтересів суспільства і конкретної } \\
\text { людини; пріоритет загальнолюдських } \\
\text { цінностей життя і здоров'я; сприяння } \\
\text { утвердженню національної ідеї, підґрунтям } \\
\text { якої є є паціональна духовність, } \\
\text { громадянськість, любов до Батьківщини. }\end{array}$ \\
\hline $\begin{array}{l}\text { Раціоналістична модель освіти } \\
\text { П. Блум, Р. Ганьє, Б. Скіннер та ін. }\end{array}$ & $\begin{array}{c}\text { Пролонгована модель професійного } \\
\text { розвитку }\end{array}$ \\
\hline Забезпечення засвоєння знань, & Модель передбачає циклічне проведення \\
\hline
\end{tabular}


умінь, навичок і передавання культурних цінностей 3 метою практичного пристосування до сучасного суспільства та наявних суспільних структур.

В основу

покладено

Біхевіористську концепцію соціальної інженерії.

Йдеться про порівняно пасивну ролі учнів, що, одержуючи певні знання, уміння і навички, адаптивний «поведінковий репертуар», необхідний для адекватного життєвлаштування відповідно до соціальних норм, вимог і запитів суспільства.

Модель не передбачає творчості, самостійності, індивідуалізації, природності тощо. Освітньому процесу притаманні дух обмеженого утилітаризму й нав'язування педагогові негнучкого і механічного способу дій. Ідеал точна запропонованому шаблону, діяльність перетворюється на посилену підготовку учнів чи студентів (наприклад, на виконання тестів). здобувають, таким чином,

курсів підвищення кваліфікації з поєднанням різних форм навчання. Пролонгована компетентнісна модель професійного розвитку забезпечує неперервність освіти вчителя за допомогою відкритого традиційного та інформаційно-освітнього середовищ післядипломної педагогічної освіти на основі діагностики рівня компетентності та різнорівневих програм за чітко визначеними етапами:

1 етап - діагностика рівнів різних компетентностей вчителів на основі самооцінки та виконання спеціальних завдань; 2 етап - очна або змішана форма навчання «перевернутий клас» (тренінги, лекціїпрезентації, відеолекції тощо); 3 етап навчання 3 використанням традиційного офлайн або дистанційного онлайн середовищ, де розміщуються спеціально розроблені модулі навчальних курсів, тексти самостійних робіт, відео-матеріали, майстер-класи, тренажери, підсумкові тести тощо.

Розуміння культури відбувається через розвиток освіченості (предметні знання, уміння, навички, способи творчої діяльності) й професійної компетентності (компоненти професіоналізму, виражені через якості особистості: відповідальність, висока моральність, творчість, допитливість, прагнення до нових знань, естетичне сприйняття дійсності).

Практична реалізація культурологічного підходу відбувається завдяки збільшенню культуромісткості та гуманітарного спрямування змісту безперервної педагогічної освіти.

\section{Диверсифікована модель}

В. Давидов, В. Рубцов та ін.

Модель передбачає

організацію освіти як особливої інфраструктури через широку кооперацію діяльності освітніх систем різного рангу, типу та рівня, що дозволяє забезпечувати та задовольняти потреби різних верств населення в освітніх послугах, забезпечувати розширення їх спектру; швидко вирішувати освітні завдання. Така освіта може бути більш затребуваною іншими сферами
Модель спрямована на залучення до професійного розвитку педагогів якомога більшої кількості зацікавлених організацій, як освітніх, так і громадських, і комерційних. Учителеві, який вибудовував індивідуальну освітню траєкторію професійного розвитку, надаються різні варіанти професійного зростання, свобода вибору фрорм, методів, установ для підвищення кваліфрікації.

В умовах Нової української школи діють освітні платформи, сайти, блоги установ безперервної педагогічної освіти, місцевих науково-методичних кабінетів (центрів), які 
прямо, без додаткових погоджень 3 державною владою. У цьому випадку сфера освіти виступає як ланка соціальної практики.
Феноменологічна модель освіти
А. Маслоу,
А. Комбс,

К. Роджерс та ін.

Модель освіти передбачає персональний характер навчання з урахуванням індивідуальнопсихологічних особливостей учнів, дбайливе і шанобливе ставлення до їх інтересів і потреб. Освіту вона найбільш повно, адекватно відповідала справжній природі людини, допомагала їй знайти те, що в ній вже закладено природою).

Педагоги створюють умови для самопізнання і підтримки унікального розвитку кожного учня у відповідності з успадкованою їм природою, надають більше свободи вибору і умов для самореалізації. Важливим $€$ право індивіда на автономію розвитку. розглядають як гуманістичну (щоб

забезпечують професійний розвиток учителя 3 використанням електронних освітніх ресурсів та надають підтримку слухачам у міжкурсовий період.

Модель передбачає інтеграцію загальнокультурної та функціональної складових професійної підготовки на підставі міждисциплінарного аналізу та суміжних людинознавчих дисциплін.

Диференційована модель

Освітній процес у системі безперервної освіти будується на засадах варіативності і передбачає наявність значної кількості різних навчальних планів, курсів, графіків для кожної категорії педагогів, які вибираються кожним слухачем залежно від індивідуальних потреб.

Слухачі можуть навчатися й у віртуальних методичних кабінетах, електронні освітні ресурси яких побудовано на принципах достатності, модульності, індивідуальності, варіативності, унікальності, адаптивності, мінімізації витрат.

Компонентами, які забезпечують розвиток педагога як суб'єкта культури, є: аксіологічний (осмислення методологічних засад освітньої парадигми та вибір особистісно значущої системи ціннісних орієнтацій); когнітивний (збагачення новітніми науковими знаннями про людину, культуру, історію, природу, ноосферу як підґрунтя духовного розвитку); діяльнісно-творчий (формування та розвиток творчих здібностей, здатність до самореалізації в професійній діяльності); особистісний (самопізнання, здатність до рефрлексії, самоактуалізація). самоудосконалення, Особистісно орієнтована модель

\section{освіти}

П. Гудман, І. Ілліч, ж. Гудлед Ф. Клейн, Дж. Холт, Л. Бернар та ін.

Освітня модель орієнтована на організацію освіти поза соціальними інститутами. Це освіта «на природі», за допомогою мережі «Internet», в умовах «відкритих шкіл», дистанційної форми навчання тощо.
Освітня модель уособлює посилення значення самоосвіти педагогів. Упровадження дистанційних і змішаних технологій навчання дозволяє забезпечити індивідуалізацію професійного розвитку педагога відповідно до його потреб та рівня компетентності, взяти особисту відповідальність за власний професійний розвиток (самостійний вибір відкритих онлайн ресурсів для профресійного 
розвитку, тестування, наявність сертифікатів). Важливими чинниками розвитку педагога $є$ його особистісна орієнтація на саморозвиток і самоудосконалення професійної компетентності та загальної культури, що позитивно впливає на виконання професійних обов'язків (розвиваються культура емоцій, інтелекту, поведінки, спілкування, зовнішнього вигляду, організації середовища, мови та мовлення тощо).

У системі безперервної освіти педагог удосконалюється як суб’єкт культури та індивідуальність зі сформованими культурно-ціннісними орієнтирами, творчою настановою на педагогічну взаємодію та реалізацію власних культурних позицій у професійній діяльності. Незалежно від моделей професійного розвитку вчителя соціокультурний підхід до визначення змісту безперервної педагогічної освіти має забезпечити такі концептуальні аспекти:

- світоглядно-філософський (розвиток ціннісних соціокультурних орієнтацій у професійній діяльності);

- соціальний (вироблення власного соціокультурного та професійного досвіду);

- методологічний (культурологічне підґрунтя освітнього процесу);

- психологічний (усвідомлення себе суб'єктом культури, носієм національної ментальності);

- дидактичний (розвиток усіх сфер особистості за технологією діалогу культур);

- методичний (розвиток здатності до культуротворчої професійної діяльності).

Висновки і перспективи подальших досліджень. Отже, сучасна безперервна педагогічна освіта, як невід'ємна складова соціального, політичного, економічного, духовного та культурного розвитку суспільства, вимагає не лише удосконалення освітньої діяльності педагогів у зовнішньому оточенні, але й їхнього постійного внутрішнього соціокультурного удосконалення. Безперервна освіта в сучасних умовах $€$ таким же необхідним компонентом життєтворчості педагога, як і навчання для дитини. Підвищення педагогічної кваліфікації - це підвищення рівня професійної майстерності вчителя шляхом удосконалення як загальнопедагогічних, так і соціальнокультурних компетентностей та загальнолюдських цінностей, які забезпечать успішне вирішення як професійних завдань, так і глобальних гуманітарних, екологічних, економічних та інших завдань.

Перспективним напрямом подальших досліджень уважаємо опанування сучасним інструментарієм освітньої діяльності для повнішої реалізації соціальної, гуманітарної, культуротворчої функцій, забезпечення гармонізації науково-предметних, світоглядно-методологічних, дидактичних, психологічних знань та соціокультурних морально-етичних цінностей вчителя. 


\section{Список використаних джерел}

Баніт, О. В. (2016). Відображення концептуальних положень неперервного професійного розвитку дорослих у міжнародних документах. Адаптивне управління: теорія $і$ практика, 1. URL: https://lib.iitta.gov.ua/705943/1/banit.pdf.

Даниленко, Л.І. (2004). Управління інноваційною діяльністю в загальноосвітніх навчальних закладах: Монографія. К.: Міленіум, 358.

Закон України «Про вищу освіту». (2012). Урядовий кур'єр. 15 червня. (86). 5-16. Закон України «Про освіту». (2021). Відомості Верховної Ради, № 38-39, 380.
Редакція
від
02.10.2021.
URL:

https://zakon.rada.gov.ua/laws/show/2145-19\#Text

Лук'янова, Л.Б., \& Аніщенко, О.В.(2017). Освіта дорослих в Україні: нові можливості для розвитку педагогічної освіти і практики. Наукове забезпечення розвитку освіти в Україні: актуальні проблеми теорії i практики (до 25-річчя НАПН України), 267-275. URL: https://lib.iitta.gov.ua/709266

Олійник, В. В. (2001). Дистанційне навчання в післядипломній педагогічній освіті: організаційно-педагогічний аспект: Навч. посібник. К.: ЦІППО, 2001. 148 c.

Ортинський, В. Л. (2009). Педагогіка вищої школи: навч. посіб. К.: Центр учбової літератури, 472.

Післядипломна педагогічна освіта України: сучасність і перспективи розвитку (2005): Наук.-метод. посібник. За заг. ред. В.В. Олійника, Л.І. Даниленко. К.: Міленіум, 230.

Про схвалення Концепції реалізації державної політики у сфері реформування загальної середньої освіти «Нова українська школа» на період до 2029 року. (2016). Розпорядження Кабінету Міністрів України від 14 грудня 2016 р., $\quad$ № 988-p. https://zakon.rada.gov.ua/laws/show/988-2016-\%D1\%80\#n2

\section{References (translated and transliterated)}

Banit, O.V. (2016). Vidobrazhennya kontseptual'nykh polozhen' neperervnoho profesiynoho rozvytku doroslykh u mizhnarodnykh dokumentakh [Reflection of conceptual provisions of continuous professional development of adults in international documents]. Adaptyvne upravlinnya: teoriya i praktyka - Adaptive control: theory and practice URL: //lib.iitta.gov.ua/705943/1/banit.pdf [in Ukrainian].

Danylenko L. (2004). Upravlinnia innovaciynou diyalnistu v zagalnoosvitnih zakladah: Monografia [Management of innovative activity in general educational establishments]. K.: Milenium, 2004. 358 [in Ukrainian].

Zakon Ukrainy «Pro Vyshu Osvitu». (2012) [Law of Ukraine «About Higher Education»]. Uriadovyi kurier - Governmental courier. 15 chervnia (86), 5-16 [in Ukrainian].

Zakon Ukrainy "Pro Osvitu». (2017). [Law of Ukraine is «About Education]. Vidomosti Verhovnoi Rady - Lists of Verhovna Rada, № 38-39, 380. Redakcia vid 02.10.2021. URL: https://zakon.rada.gov.ua/laws/show/2145-19\#Text [in Ukrainian].

Luk'yanova, L.B., Anishchenko, O.V. (2017). Osvita doroslykh v Ukrayini: novi 
mozhlyvosti dlya rozvytku pedahohichnoyi osvity i praktyky [Adult education in Ukraine: new opportunities for the development of pedagogical education and practice]. Naukove zabezpechennya rozvytku osvity v Ukrayini: aktual'ni problemy teoriyi i praktyky (do 25-richchya NAPN Ukrayiny) - Scientific support of education development in Ukraine: current issues of theory and practice (to the 25th anniversary of the NAPS of Ukraine, 267-275. URL: https://lib.iitta.gov.ua/709266 [in Ukrainian].

Oliynyk, V. (2001). Dystanciyne navchannya $v$ pislyadyplomhiy pedagogichniy osviti: organizaciyno-pedagogichny aspect: navch.posibnyk [Distance studies in retraining pedagogical education: organizationally-pedagogical aspect]. K.: CIPPO, 148 [in Ukrainian].

Ortynskiy, V.L. (2009). Pedagogika vyshoi shkoly: navchal'nyy posibnyk [Pedagogics of high school]. K.: Tsentr uchbovoyi literatury. 472. [in Ukrainian].

Pisliadyplomna pedagogichna osvita Ukrainy: suchasnist I perspectyvy rozvytku: nauk.-metod. posibnyk za zag. Red. V. Oliynyka, L. Danylenka. [Retraining pedagogical education of Ukraine: contemporaneity and prospects of development]. K., Milenium, 2005. 230 [in Ukrainian].

Pro shvalennya Koncepcii realizacii derzhavnoi polityky u sferi reformuvannia zagalnoi serednioi osvity «Nova Ukrainska Shkola» na period do 2029 poku [About approval of Conception of realization of public policy in the field of reformation of universal middle education «New Ukrainian School» on a period 2029 to]. (2016). Rozporiadzhennia Kabinetu Ministriv Ukrainy vid 14 grudnia 2016 r. № 988-p URL: https://zakon.rada.gov.ua/laws/show/988-2016-\%D1\%80\#n2 [in Ukrainian].

\title{
УДК 374.7
}

DOI: https://doi.org/10.35387/od.2(20).2021.101-108

\begin{tabular}{|c|c|}
\hline 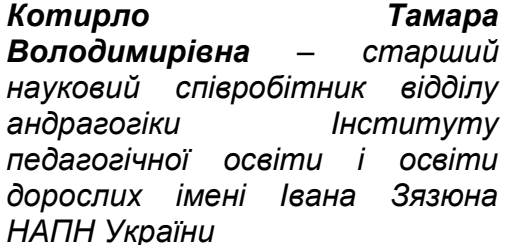 & $\begin{array}{l}\text { Kotyrlo Tamara } \\
\text { Researcher of the } \\
\text { Department of the } \\
\text { Institute of Pedagogic } \\
\text { Education of the NAE }\end{array}$ \\
\hline
\end{tabular}

\section{ПРОФЕСІОНАЛІЗАЦІЯ ПЕДАГОГІЧНОГО ПЕРСОНАЛУ ЗАКЛАДІВ ВИЩОЇ ОСВІТИ: ПРОБЛЕМИ ТА ШЛЯХИ ПОДОЛАННЯ}

\begin{abstract}
Анотація. Автором оглядової статті проаналізовано актуальні дослідження щодо профресіоналізації педагогічного персоналу закладів вищої освіти в Україні. Наведено погляди дослідників щодо сутності
\end{abstract}

